https://doi.org/10.37208/tgn27313

\section{The landhopper Arcitalitrus dorrieni (Crustacea: Amphipoda) in Glasgow Botanic Gardens, Scotland}

\author{
R.B. Weddle \\ 89 Novar Drive, Glasgow G12 9SS \\ E-mail: richard@canto.plus.com
}

The landhopper Arcitalitrus dorrieni (Hunt, 1925) was not mentioned in Hancock's original account of the invertebrates in Glasgow Botanic Gardens (Hancock, 1999) but was first discovered there during a Bioblitz in 2017 and has been seen in each subsequent year to 2020 (pers. obs.). Indeed, the species was not found in Glasgow until 2009, when it was discovered beside the River Kelvin in Bunhouse Road, Glasgow (Hancock, 2012).

A. dorrieni is the U.K.'s only truly terrestrial amphipod (shrimp-like crustacean) and is typically found in damp leaf-litter. In Glasgow Botanic Gardens it is found close to the stone wall boundary at the Victorian houses of Kirklee Circus, and on the edges of the woodlands sloping down to the River Kelvin opposite. Hancock's 2009 sighting was the first in the mainland part of the Clyde area, though it was previously recorded in many Hebridean islands, and it now seems to be widespread in western coastal areas, having been seen in the Isle of Bute, Dunoon and several other towns in the Clyde area, particularly in cemeteries and parks (G. Collis, pers. comm.; Collis \& Collis, 2016).

The author, with The Conservation Volunteers, also found A. dorrieni in 2019 beside the River Kelvin in Kelvingrove Park during a Bioblitz, and Hancock also found it at Bellahouston Park, Glasgow (Hancock, 2012), so it is clearly widespread in Glasgow. (Fig. 1).

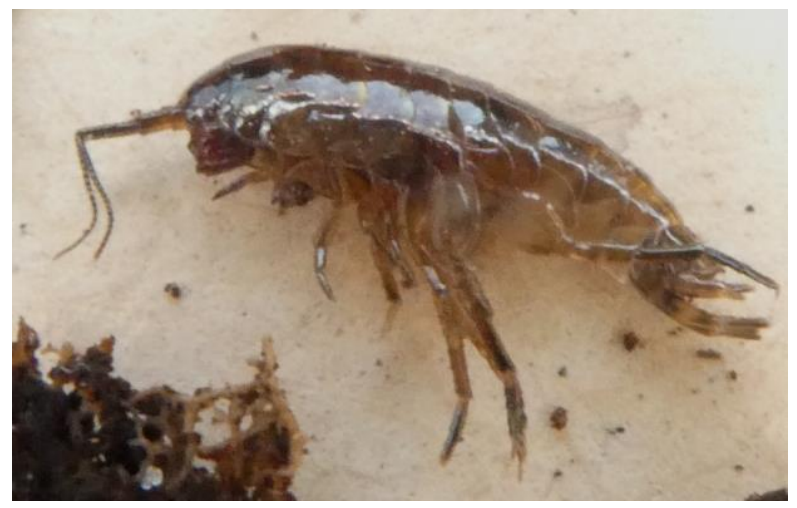

Fig. 1. A specimen of the landhopper Arcitalitrus dorrieni, found in Glasgow Botanic Gardens, August 2020; length $8 \mathrm{~mm}$. (Photo: R.B.Weddle)
There is another similar species in the U.K. - the introduced semi-terrestrial amphipod Cryptorchestia cavimana (Heller, 1865), which is less darkly pigmented and, although able to penetrate far inland, rarely strays far from water margins (British Myriapod and Isopod Group, 2020). The Botanic Gardens specimens were identified as A. dorrieni using the key in Gregory (2016) and a specimen has been retained.

A map showing further U.K. and Ireland records of A. dorrieni can be seen at https://species.nbnatlas.org/species/NBNSYS00001884 75 but at the time of writing this does not include any of the records mentioned in this note, nor those given in Gregory (2016), which show its presence in the northeast of England. It appears to be synanthropic (i.e. it is an undomesticated species living in close association with humans), probably spread via plant nurseries and garden centres, as there seems to be a link with ornamental gardens (Gregory, 2016). This is attested in the Clyde area by its presence in Benmore Gardens near Dunoon (Collis \& Collis, 2016) and Hancock's record at Bellahouston Park was in the area of the plant nursery (Hancock, 2012).

I am grateful to Glasgow Museums Biological Records Centre for producing the full species list, and for details of some of the individual records cited; and to Glyn and Dawn Collis for additional information about the distribution in the Clyde area.

\section{REFERENCES}

British Myriapod and Isopod Group (2020). www.bmig.org.uk/species/arcitalitrus-dorrieni Accessed 15th August 2020.

Collis, G.M. \& Collis, V.D. (2016). The Australian landhopper, Arcitalitrus dorrieni in Islay and in Cowal. The Glasgow Naturalist 26(2), 92-93.

Gregory, S.J. (2016). On the terrestrial landhopper Arcitalitrus dorrieni (Hunt, 1925) (Amphipoda: Talitridae): identification and current distribution. Bulletin of the British Myriapod and Isopod Group 29, 2-13.

Hancock, E.G. (1999). Hidden wildlife: the resident population of invertebrates. The Glasgow Naturalist 23(4), 59-64.

Hancock, E.G. (2012). The Australian landhopper, Arcitalitrus dorrieni (Hunt, 1925) (Crustacea: Amphipoda) in Glasgow. The Glasgow Naturalist 25(4), 130 . 